\title{
Spatial distribution of aquifers in Bhairahawa-Lumbini area, Rupandehi district, west Nepal
}

\author{
Narendra Khattri \\ Bhairahawa-Lumbini Groundwater Irrigation Project, \\ Siddhartha Nagar, Rupandehi, Nepal \\ (Email:nkhattri2004@yahoo.com)
}

\begin{abstract}
The Bhairahawa-Lumbini Groundwater Irrigation Project (BLGWIP) is the largest groundwater development project of Nepal. It is situated in the middle of the Rupandehi district in west Nepal. The project covers an area of about $525 \mathrm{sq} \mathrm{km}$ and serves over 20,000 ha of land by providing year-round irrigation. Over 180 deep tubewells were constructed by the BLGWIP within the area stretching between the Rohini River in the east and the Kothi River in the west with the depth ranging from 80 to over $200 \mathrm{~m}$.
\end{abstract}

Seven different sections were taken to study the subsurface geology and nature of aquifer in this area. These seven sections include 61 deep tubewells. The lithological cross-sections show the distribution of pervious and impervious layers. The study shows that the aquifer materials are controlled by two major rivers: the Tinau River and Dano River. The lithological cross-sections I-I' and VII-VII' are taken from extreme west and east of the study area, respectively. Clay and silt horizons are predominant in both sections. On the other hand, the remaining cross-sections II-II', III-III', IV-IV', V-V', and VI-VI' are taken from the central part of the study area. The litholog of boreholes of these sections show a significant amount of sand and gravel.

Most of the deep aquifers recharge from infiltration of rainfall in the Bhabar Zone and also from the induced infiltration through the Tinau, Dano, Rohini, and other rivers flowing through the district. The study shows that the input to groundwater is as high as 464 million cubic metres (MCM). Out of this, $201 \mathrm{MCM}$ goes into the shallow aquifers and $267 \mathrm{MCM}$ flows into the deep aquifers.

\section{INTRODUCTION}

The Bhairahawa-Lumbini Groundwater Irrigation Project (BLGWIP) is the largest groundwater development enterprise of Nepal. It is situated in the middle of the Rupandehi district in west Nepal (Fig. 1). It occupies about $525 \mathrm{sq} \mathrm{km}$ and extends about $35 \mathrm{~km}$ in the east-west direction and $15 \mathrm{~km}$ in the north-south direction. The project serves over 20,000 ha of land by providing year-round irrigation.

Over 180 deep tubewells were constructed by the BLGWIP within the area stretching between the Rohini River in the east and the Kothi River in the west. Their depth ranged from 80 to over $200 \mathrm{~m}$.

The project area stretches within an enormous alluvial plain, which extends for about $30 \mathrm{~km}$ between the foothills in the north and the Nepal-India border in the south. The thickness of alluvial deposits may reach up to $2000 \mathrm{~m}$ in the south and probably more along the foothills in the north. The alluvium is made up mainly of the clastic material, i.e., sand, silt, and gravel interbedded with clay and silt. The silt and clay horizons help to separate various aquifers.

The aquifers are classified into shallow $(\leq 50 \mathrm{~m})$ and deep $(>50 \mathrm{~m})$. The thickness and depth of different aquifers comprising gravel and sand horizons vary significantly. A majority of wells were artesian and their water level reached $10 \mathrm{~m}$ above ground level at the initial stage of development.

\section{AQUIFER CHARACTERISTICS}

The study of hydrogeological parameters of aquifers is important for evaluation, exploration, and management of groundwater resources. The aquifer characteristics help to assess the transmissivity, storage capacity, interconnection with other aquifers, and sources of recharge. They also provide a basis for determining the water supply availability from a particular tubewell. But, much of the success in groundwater exploration, development, utilisation, and management depends on the accurate evaluation of the hydraulic parameters. 


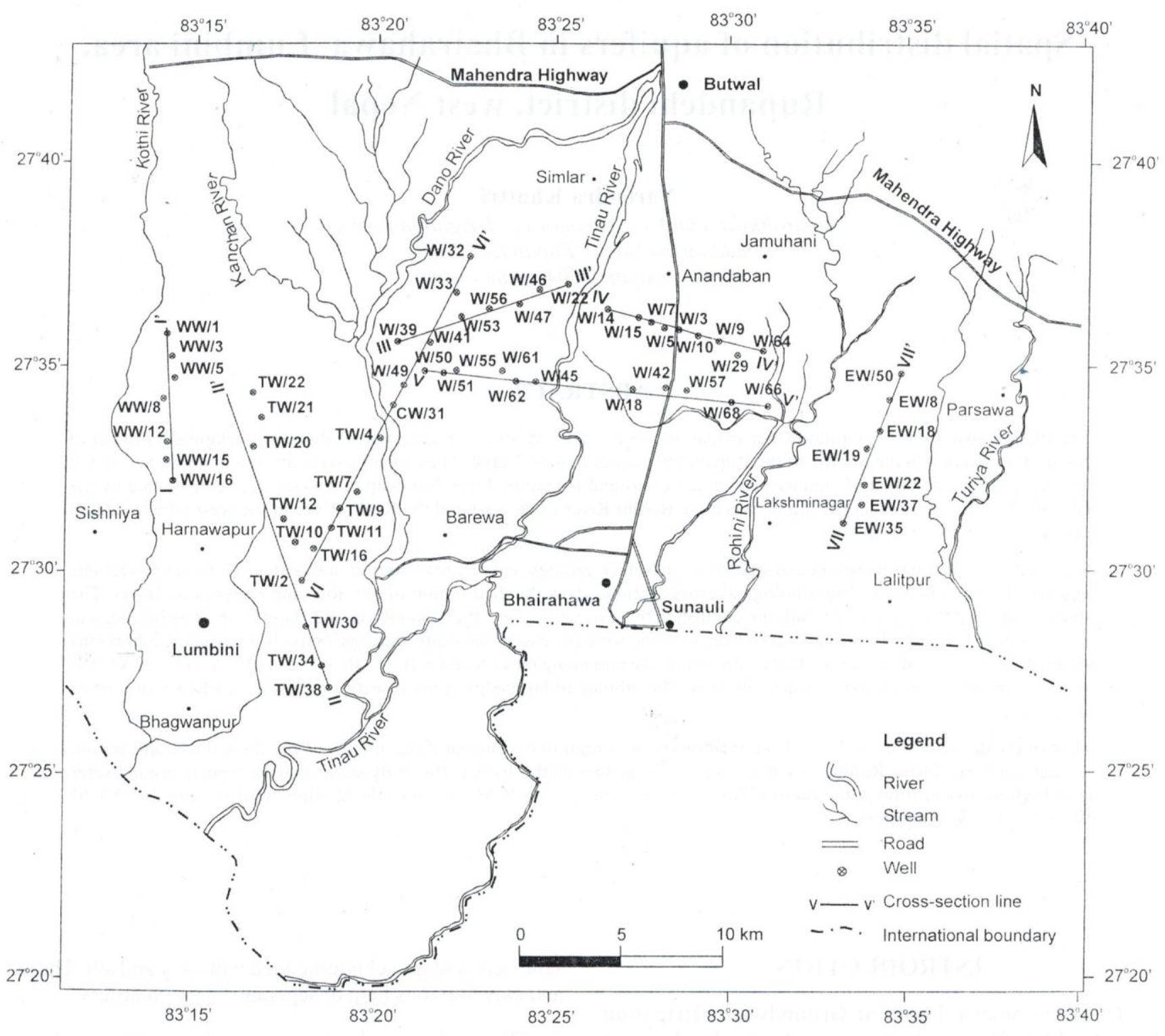

Fig. 1: Well distribution map of the project area

The aquifer characteristics of the BLGWIP are summarised as follows:

- Static water level (SWL) ranges from -10.5 m (below ground level) to $+9.35 \mathrm{~m}$ (above ground level);

- Tested discharge ranges from a minimum of $250 \mathrm{~m}^{3} / \mathrm{hr}$ to a maximum of $671 \mathrm{~m}^{3} / \mathrm{hr}$;

- Free flow ranges from a minimum of $15 \mathrm{~m}^{3} / \mathrm{hr}$ to a maximum of $540 \mathrm{~m}^{3} / \mathrm{hr}$;

- Drawdown ranges from $2.12 \mathrm{~m}$ (at $518 \mathrm{~m}^{3} / \mathrm{hr}$ ) to 45.17 $\mathrm{m}\left(\right.$ at $\left.300 \mathrm{~m}^{3} / \mathrm{hr}\right)$;
- Transmissivity ranges from $326 \mathrm{~m}^{2} / \mathrm{day}$ to $40,306 \mathrm{~m}^{2} / \mathrm{day}$; and

- Permeability ranges from $11.26 \mathrm{~m} /$ day to $1,006 \mathrm{~m} /$ day.

\section{LITHOLOGICAL CROSS-SECTIONS}

Based on the lithology of existing tubewells, seven sections were selected for the purpose of constructing geological sections (Fig. 1). These sections characterise to a large extent the subsurface stratigraphy (Table 1). 
Table 1: Average per cent of aquifers and aquitards at various lithological cross-sections

\begin{tabular}{c|c|c|c|c|c}
\hline $\begin{array}{c}\text { Lithological } \\
\text { cross-section }\end{array}$ & $\begin{array}{c}\text { Depth of } \\
\text { Tubewell (m) }\end{array}$ & $\begin{array}{c}\text { Thickness of } \\
\text { aquitard (m) }\end{array}$ & $\begin{array}{c}\text { Thickness of } \\
\text { aquifer (m) }\end{array}$ & $\begin{array}{c}\text { Percentage of } \\
\text { aquitard (\%) }\end{array}$ & $\begin{array}{c}\text { Percentage of } \\
\text { aquifer (\%) }\end{array}$ \\
\hline I-I' & 149 & 112 & 37 & 75 & 25 \\
\hline II-II' & 174 & 109 & 65 & 63 & 37 \\
\hline III-III' & 155 & 58 & 97 & 37 & 63 \\
\hline IV-IV' & 125 & 48 & 77 & 38 & 62 \\
\hline V-V' & 157 & 70 & 87 & 45 & 55 \\
\hline VI-VI' & 172 & 82 & 90 & 48 & 52 \\
\hline VII-VII' & 149 & 103 & 46 & 69 & 31 \\
\hline Average & 154 & 83 & 71 & 54 & 46 \\
\hline
\end{tabular}

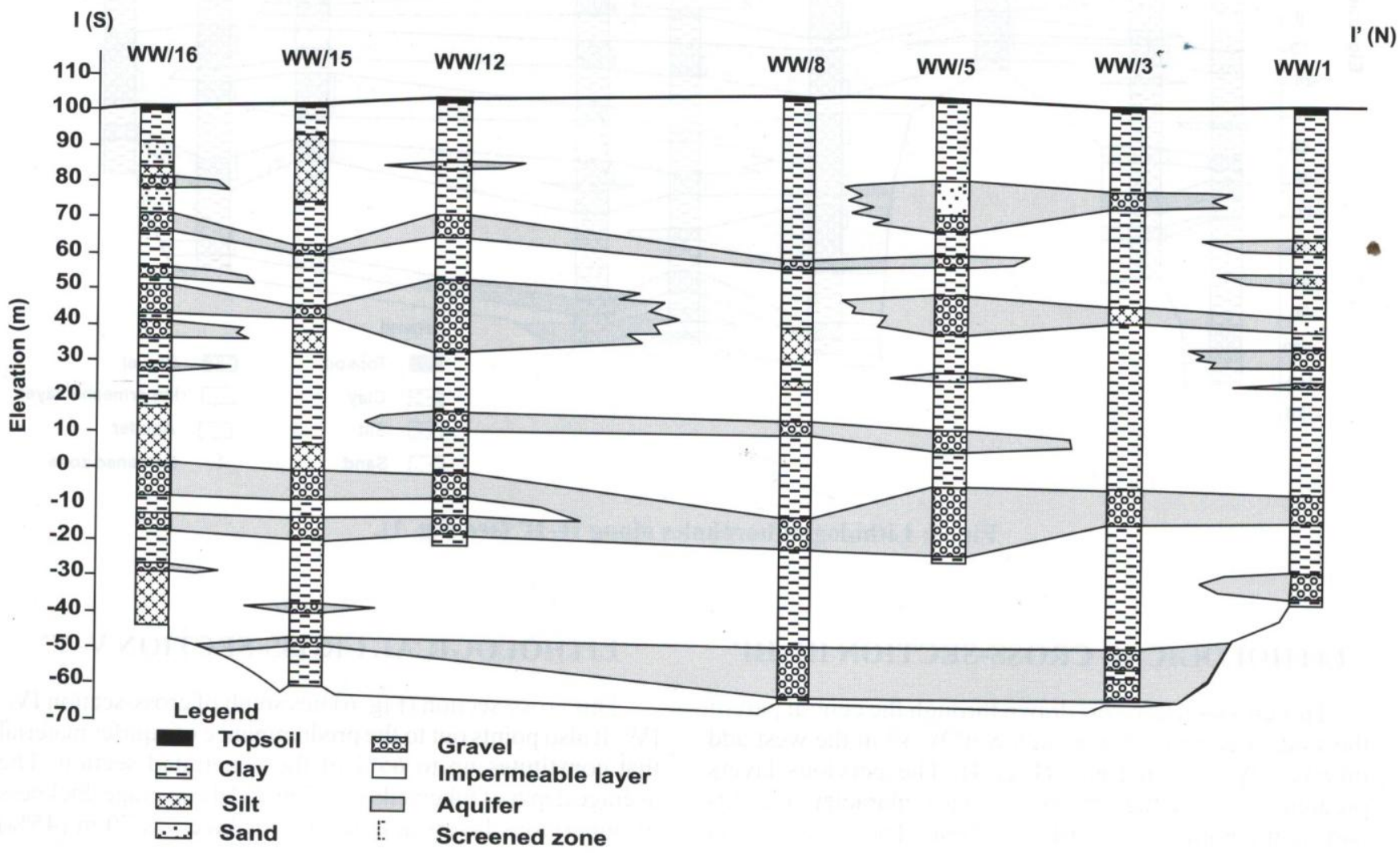

Fig. 2: Litholog of boreholes along I-I' (see Fig. 1).

\section{LITHOLOGICAL CROSS-SECTION I-I'}

This cross-section (Fig. 2) displays the stratigraphy in the western part of the area. It includes tubewell WW/16 in the south and tubewell WW/1 in the north, and shows the predominance of impervious layers ( 58 to $85 \%$ ), which are from 2 to 4 times thicker than the aquiferous beds. In this cross-section, the average depth of tubewells is $149 \mathrm{~m}$ and the average thickness of impervious layers and aquifers is 112 and $37 \mathrm{~m}$, respectively. Similarly, the average percentage of impervious and aquiferous layers is 75 and $25 \%$, respectively.

\section{LITHOLOGICAL CROSS-SECTION II-II'}

This section was drawn to the east of cross-section I-I'. The cross-section (Fig. 3) includes tubewell TW/38 in the south and tubewell $\mathrm{TW} / 22$ in the north. It shows a predominance of impervious layers (48 to $72 \%$ ) over the aquifers ( 28 to $52 \%$ ). It also indicates thickening of aquifers, as one approaches the Tinau-Dano river system. The average depth of tubewells is $174 \mathrm{~m}$ and the average thickness of impervious and aquiferous layers is $109 \mathrm{~m}(63 \%)$ and $65 \mathrm{~m}$ $(37 \%)$, respectively. 


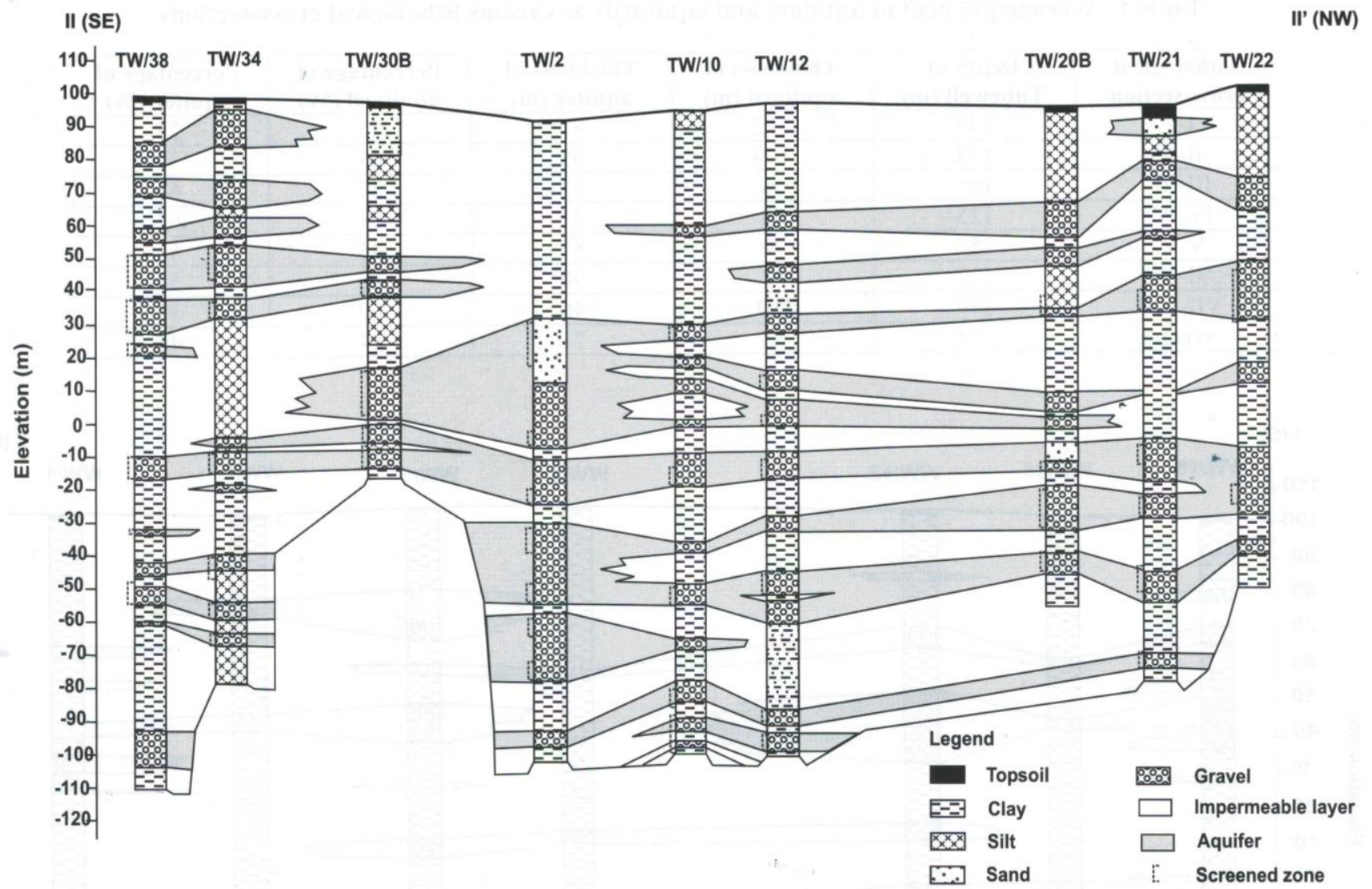

Fig. 3: Litholog of boreholes along II-II' (see Fig. 1).

\section{LITHOLOGICAL CROSS-SECTION III-III'}

This cross-section was drawn through the central part of the study area that includes tubewell W/39 in the west and tubewell W/22 in the east (Fig. 4). The pervious layers predominate over the impervious ones characterising this part as the border to the Bhabar Zone. The cross-section (Fig. 4) shows the predominance of sandy gravel (i.e., 56 to $75 \%$ ). The average depth of tubewells is $155 \mathrm{~m}$ and the average thickness of impervious layers and aquiferous layers is $58 \mathrm{~m}(37 \%)$ and $97 \mathrm{~m}(63 \%)$, respectively.

\section{LITHOLOGICAL CROSS-SECTION IV-IV'}

This cross-section (Fig. 5) includes tubewell W/14 in the west and tubewell W/64 in the east. The aquiferous layers, irrespective of the lateral distance from the Tinau River, indicate that the section passes through the border of the Bhabar Zone. The aquiferous layers are thicker in the central part, and they constitute about 55 to $71 \%$ of the penetrated section. The average depth of tubewells is $125 \mathrm{~m}$ and the average thickness of impervious layers and aquifers is 48 and $77 \mathrm{~m}$, respectively. Similarly, the average percentage of impervious and aquiferous layers is 38 and $62 \%$, respectively.

\section{LITHOLOGICAL CROSS-SECTION V-V'}

This cross-section (Fig. 6) lies south of cross-section IVIV'. It also points out to the predominance of aquifer material that constitutes up to $65 \%$ of the penetrated section. The average depth of tubewells is $157 \mathrm{~m}$ and the average thickness of impervious layers and aquiferous layers is $70 \mathrm{~m}(45 \%)$ and $87 \mathrm{~m}(55 \%)$, respectively.

\section{LITHOLOGICAL CROSS-SECTION VI-VI'}

This cross-section (Fig. 7) includes tubewell TW/2 in the southwest and tubewell W/32 in the northeast. It crosses the Dano River, and cross-sections II-II', III-III', and VV'. The cross-section shows a great variation in proportions of impervious and pervious layers. The proportion of pervious layer ranges from 30 to $67 \%$ of the penetrated section. The average depth of tubewells is $172 \mathrm{~m}$, and the average thickness of impervious layers and aquiferous layers is 82 and $90 \mathrm{~m}$, respectively. The average percentage of impervious and aquiferous layers is 48 and $52 \%$, respectively. 


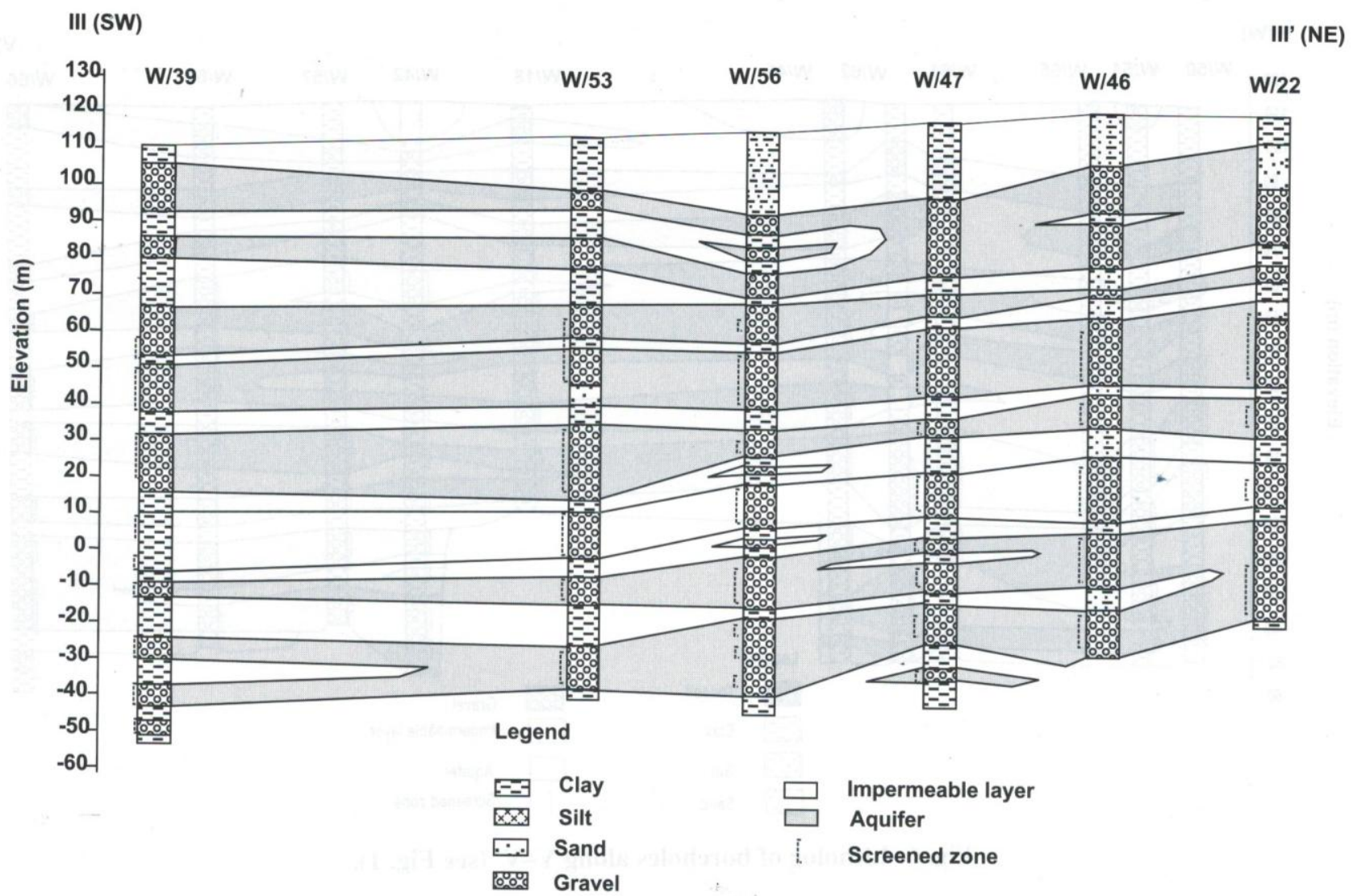

Fig. 4: Litholog of boreholes along III-III' (see Fig. 1).

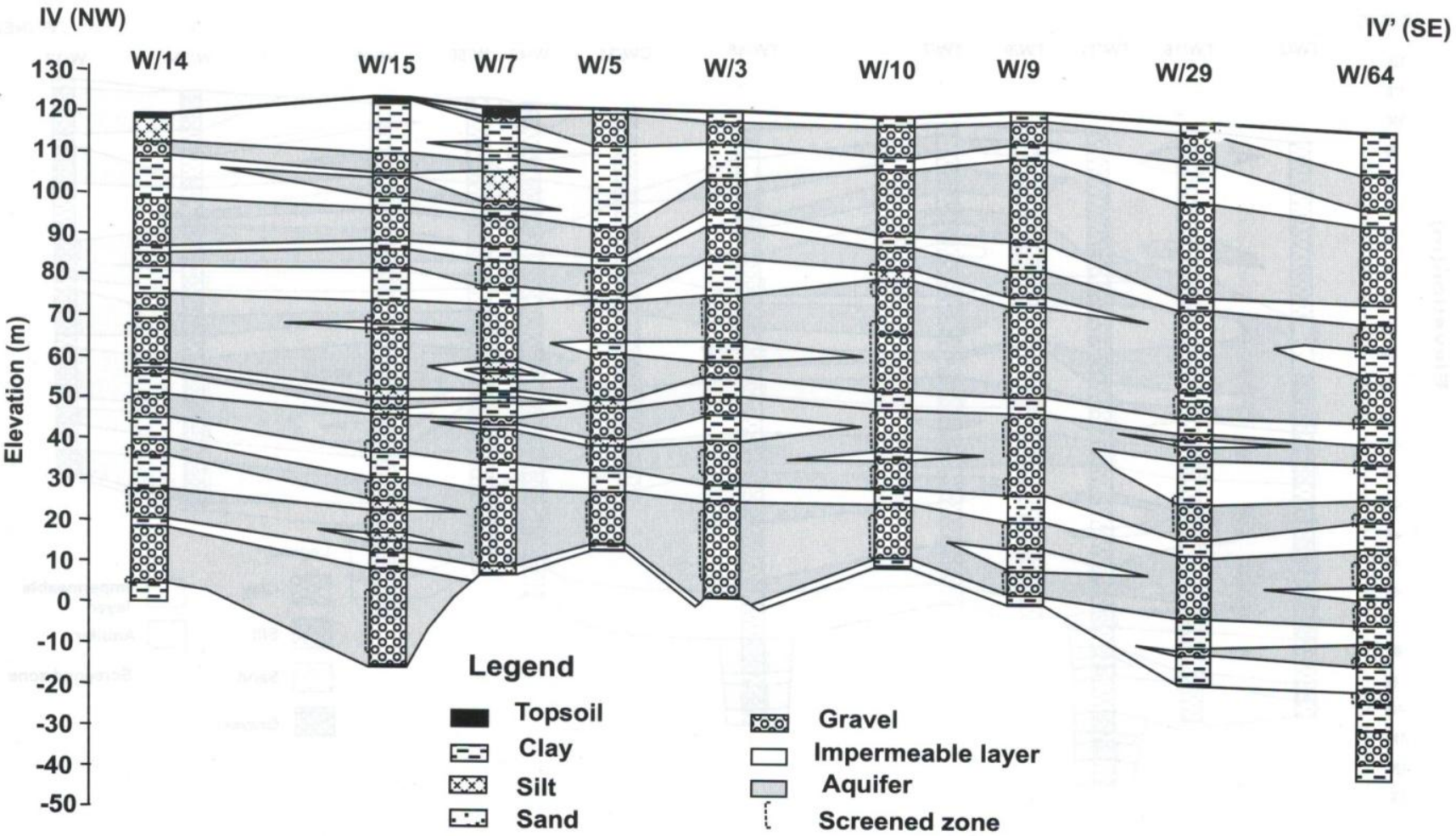

Fig. 5: Litholog of boreholes along IV-IV' (see Fig. 1). 
Narendra Khattri

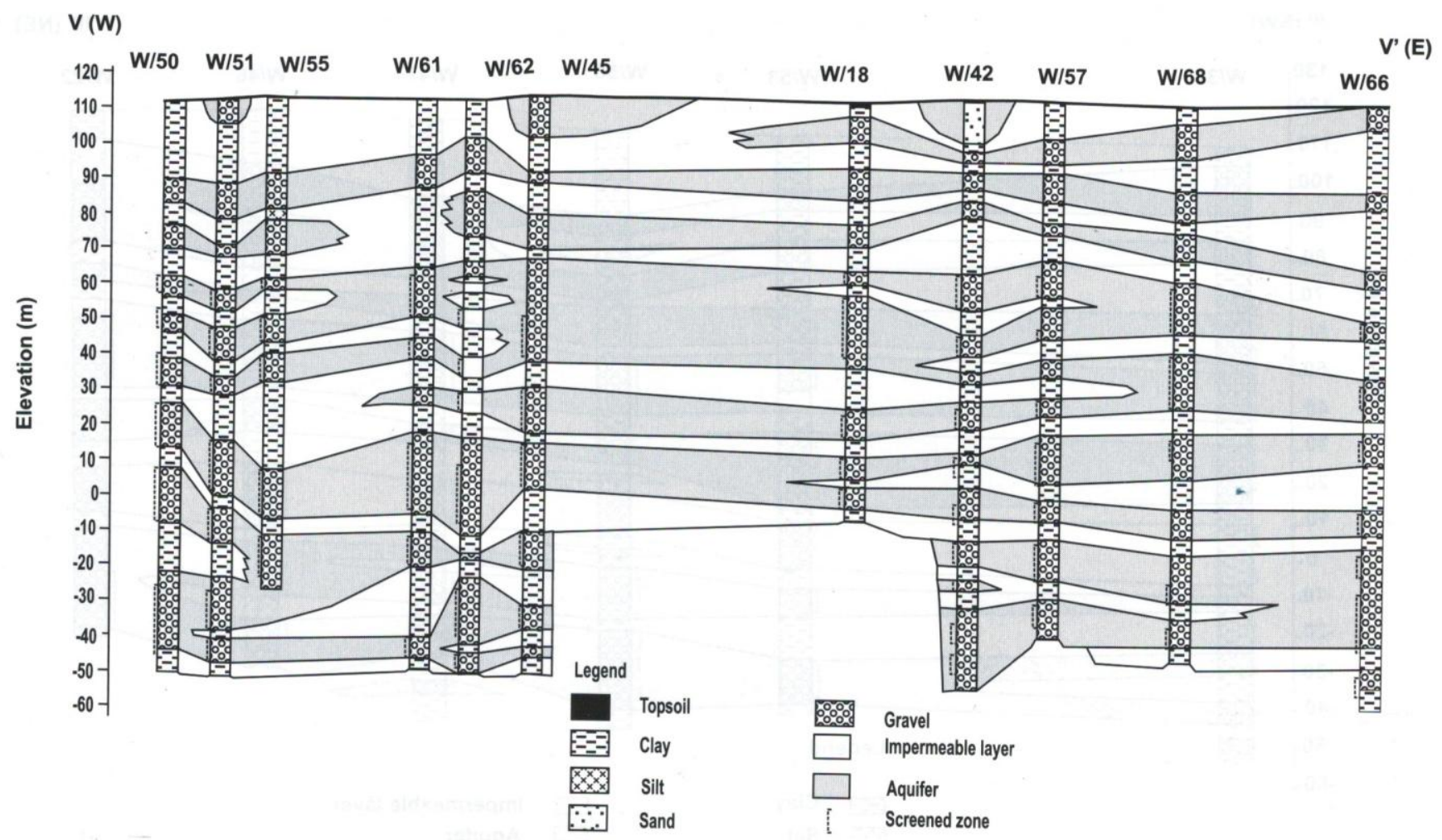

Fig. 6: Litholog of boreholes along V-V' (see Fig. 1).

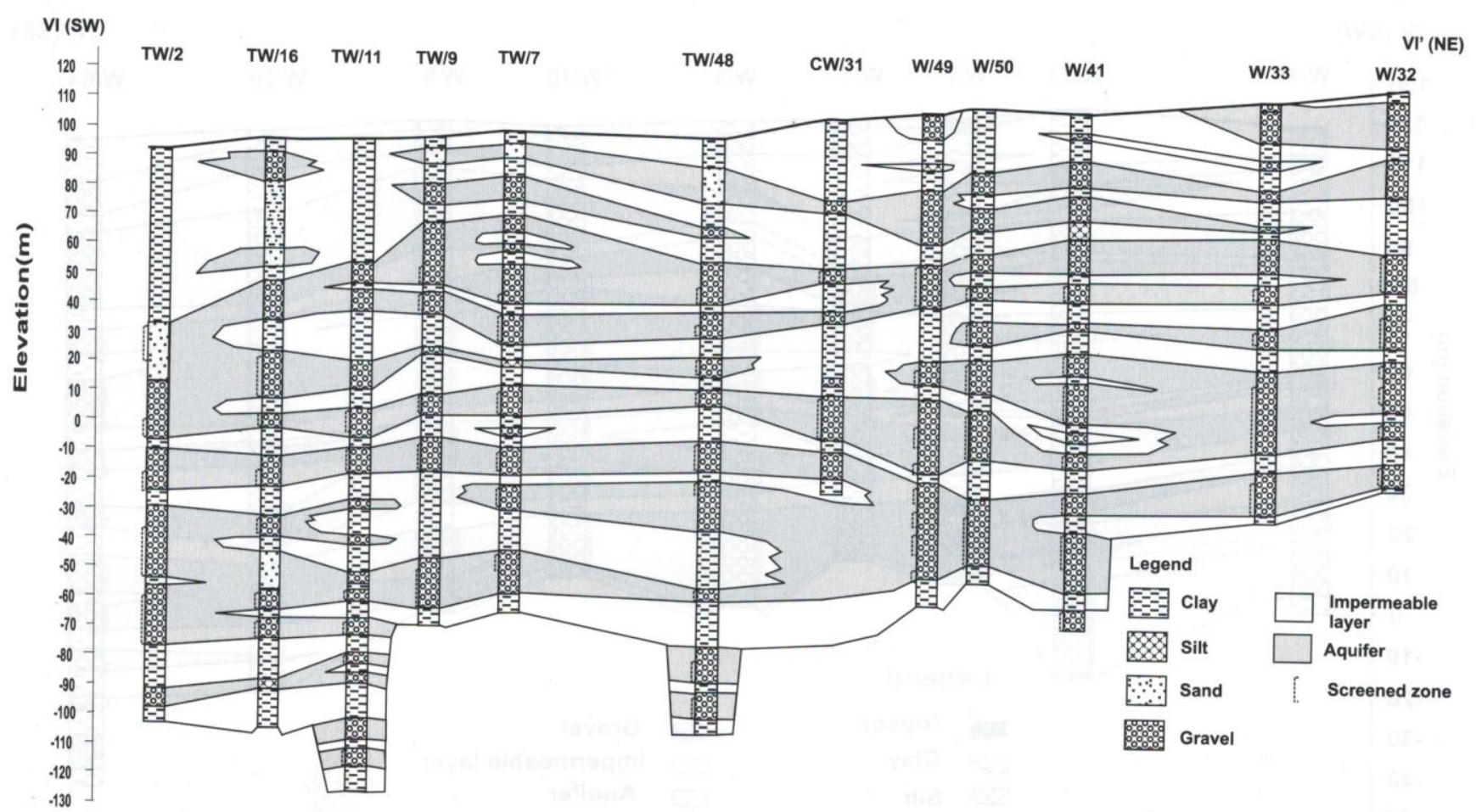

Fig. 7: Litholog of boreholes along VI-VI' (see Fig. 1). 


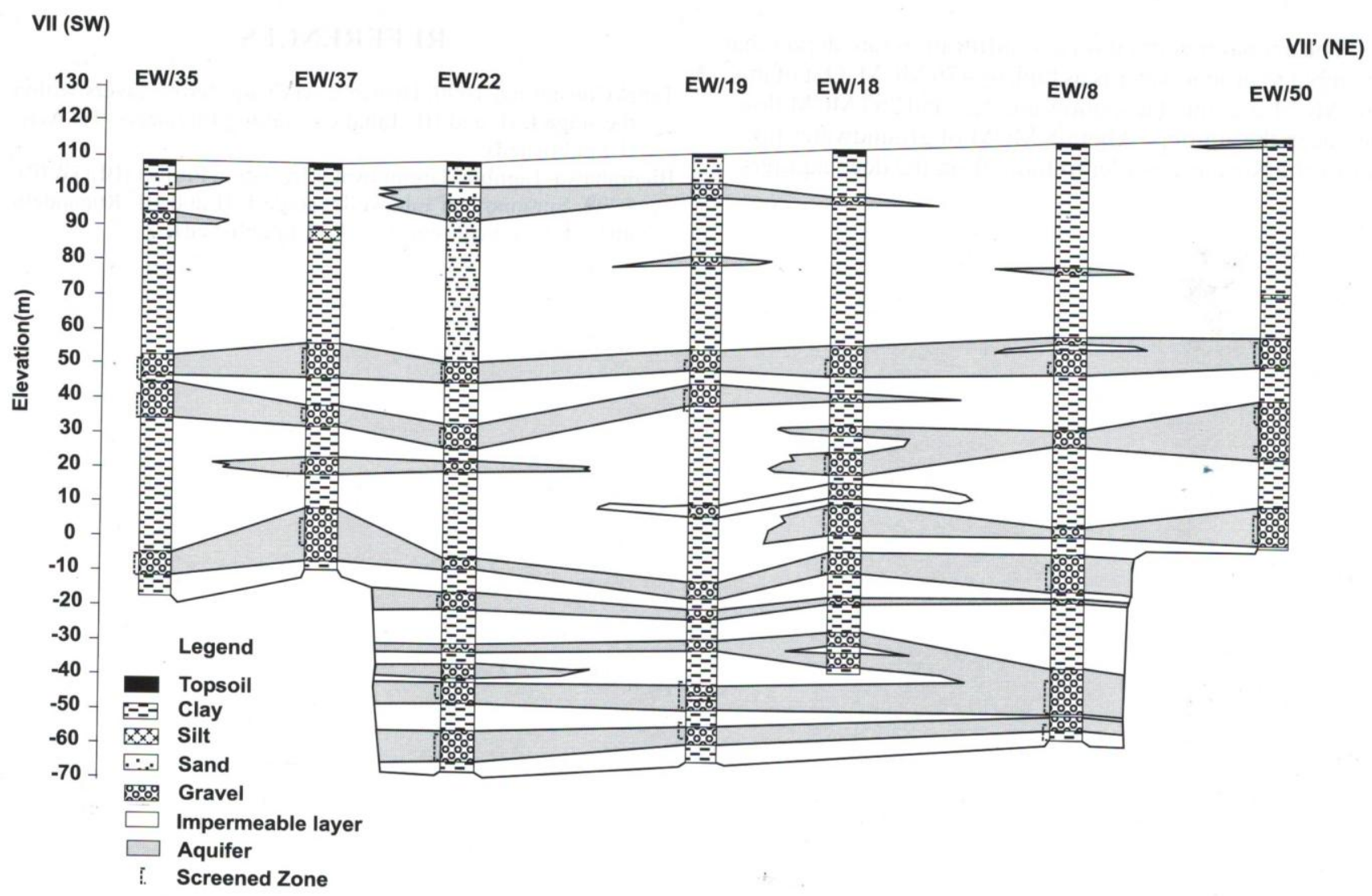

Fig. 8: Litholog of boreholes along VII-VII' (see Fig. 1).

\section{LITHOLOGICAL CROSS-SECTION VII-VII'}

This cross-section (Fig. 8) trends from northeast to southwest, and includes tubewell EW/35 in the southwest and tubewell $\mathrm{EW} / 50$ in the northeast. It is quite similar to cross-section I-I' in the western part of the study area. The percentage of aquiferous material ranges from 25 to $34 \%$ of the penetrated section and signifies the increasing proportion of fines within the Indo-Gangetic sediments in the south. The average depth of tubewells is $149 \mathrm{~m}$ and the average thickness of impervious layers and aquiferous layers is 103 and $46 \mathrm{~m}$, respectively. The average percentage of impervious and aquiferous layers is 69 and $31 \%$, respectively.

\section{GROUNDWATER RECHARGE AND BALANCE}

Most of the deep aquifers recharge from infiltration of rainfall in the Bhabar Zone and also from the induced infiltration through the Tinau, Dano, Rohini, and other rivers flowing within the district. The Bhabar Zone extends for about $510 \mathrm{sq} \mathrm{km}$ and the mean annual rainfall of the district is $2100 \mathrm{~mm} / \mathrm{yr}$ with the infiltration of about $44 \%$ into the Bhabar Zone. Hence, the input to groundwater is as high as 476 million cubic metres ( $\mathrm{M} C \mathrm{CM})$. Out of this, $201 \mathrm{MCM}$ goes into the shallow aquifers and $267 \mathrm{MCM}$ flows into the deep aquifers. It is estimated that about $8 \mathrm{MCM}$ of groundwater flows across the Nepalese border to India from the deep aquifers (BLGWIP 1998).

Assuming that about $8000 \mathrm{~m} 3 / \mathrm{yr} / \mathrm{ha}$ of groundwater is needed to irrigate $20,000 \mathrm{ha}$, only $160 \mathrm{MCM}$ will be needed to draw from the storage of deep aquifer. Considering that $25 \%$ of water requirement is met through the monsoon and winter rain, only $120 \mathrm{MCM}$ of groundwater from the deep aquifers may fulfil the required irrigation water demand. Thus, about $147 \mathrm{MCM}$ of groundwater in the deep aquifers remains in balance for further development.

\section{CONCLUSIONS}

The geology of the study area was reconstructed from seven cross-sections. Sand and sandy gravel predominate in the central part of the study area. The predominance can be attributed to the activity of the Tinau and Dano Rivers, which flow through the central part of the study area. The proportion of fines increases with increasing lateral distance from the rivers. 
The annual precipitation and infiltration rate depict that the input to groundwater is as high as $476 \mathrm{MCM}$. Out of this, 201 MCM goes into the shallow aquifers and $267 \mathrm{MCM}$ flows into deep the aquifers. About $8 \mathrm{MCM}$ of groundwater flows across the Nepalese border to India from the deep aquifers.

\section{REFERENCES}

Tahal Consulting, 1996, Distribution of aquiferous layers within the stage I, II, and III, Tahal Consulting Engineers, Tel Aviv, (Unpublished).

Bhairahawa-Lumbini Groundwater Irrigation Project (BLGWIP), 1998, Summary of tubewells: stage I, II and III, Rupandehi district, technical report, v. 4, (Unpublished). 